\title{
The Heterogeneous Nuclear Ribonucleoprotein K (hnRNP K) Interacts with Dengue Virus Core Protein
}

\author{
CHING-JIN CHANG,${ }^{1}$ HUI-WEN LUH,,${ }^{1}$ SHAO-HUNG WANG,${ }^{2}$ HUI-JIN LIN, ${ }^{1}$ SHENG-CHUNG LEE,, 3 \\ and SHIAU-TING $\mathrm{HU}^{2}$
}

\begin{abstract}
Heterogeneous nuclear ribonucleoprotein $\mathrm{K}$ (hnRNP $\mathrm{K}$ ), a component of hnRNP particles, is involved in several steps of gene expression regulation. Dengue (DEN) virus, a member of the Flaviviridae, is the primary cause of illnesses such as dengue fever, dengue hemorrhagic fever, and dengue shock syndrome. In mature DEN virus particles, the core protein is a structural protein that forms a nucleocapsid complex with genomic RNA. Very little of its biologic functions is known. Here, using an in vitro binding assay and coimmunoprecipitation analysis, we report a protein-protein interaction between the DEN virus core protein and hnRNP $\mathrm{K}$. The C-terminal hydrophilic region of the DEN virus core protein, spanning amino acid residues 73 to 100 , is required for such interaction. Results of glutathione-S transferase binding assays indicated that the core protein-hnRNP $K$ interaction might be abolished in the presence of hnRNP $K$ cognate nucleic acids. Furthermore, in a cotransfection experiment, the repressive effect of hnRNP K on C/EBP $\beta$-mediated transcription activation could be reversed by full-length DEN virus core protein but not by a truncated form containing amino acids 1-72. Our results suggest that, on DEN virus infection, the multiple functions of cellular hnRNP K may be affected by the virus core protein.
\end{abstract}

\section{INTRODUCTION}

$\mathbf{T}$ HE hnRNP K PROTEIN HAS BEEN IDENTIFIED as a component of heterogeneousnuclear ribonucleoproteincomplexes (hnRNP) (Dreyfuss et al., 1993; Weighardt et al., 1996; Krecic and Swanson, 1999). It contains both a classical nuclear localization signal and the novel $\mathrm{K}$ nuclear shuttling domain that allows it to move between the nucleus and the cytoplasm(Michael et al., 1997). The K protein is involved in several cellular processes through its binding to RNA, DNA, and multiple proteins (Bomsztyk et al., 1997). The nucleic acid-binding activity of hnRNP K is mediated by three repeats of motifs termed the $\mathrm{KH}$ (K homology) domain (which consists of 65-70 residues) and two RGG (Arg-Gly-Gly) boxes (Siomi et al., 1993; Tomonaga and Levens, 1995; Lee et al., 1996). The hnRNP K protein contains a cluster of proline-rich regions that interact with the $\mathrm{SH} 3$ domains of the proto-oncogene Vav, the Src family of tyrosine kinases, and PKC $\delta$ (Hobert et al., 1994; Van Seuningen et al., 1995; Bustelo et al., 1995; Schullery et al., 1999). The K protein may assemble on DNA as either transcriptional repressors or activators, depending on the circumstances. For example, it binds to the CT element and interacts with TATA-binding protein to activate c-myc expression (Takimoto et al., 1993; Michelotti et al., 1996). It also binds in vivo and in vitro to a zincfinger transcriptional repressor, Zik1 (Denisenko et al., 1996). Moreover, it antagonizes SP1-mediated trans-activation of the neuronal nicotinic acetylcholine receptor promoter (Du et al., 1998). We also have previously demonstrated that hnRNP K interacts with a transcriptional activator, $\mathrm{C} / \mathrm{EBP} \beta$, and inhibits $\mathrm{C} / \mathrm{EBP} \beta$-mediated activation (Miau et al., 1998). Hepatitis C virus core protein, which has been shown to modulate cellular and viral promoter activities, is also a hnRNP K-interacting protein (Hsieh et al., 1998). In addition to signal transduction and transcription, hnRNP K is implicated in translational regulation by binding to 15-lipoxygenase mRNA (Ostareck et al., 1997) and human papillomavirus type 16 L2 mRNA (Collier et al., 1998) and causing translation inhibition.

Dengue (DEN) virus belongs to the Flaviviridae family. It circulates in nature in four serologically distinct types (serotypes $1-4)$, and it can cause diseases ranging from mild dengue fever

\footnotetext{
${ }^{1}$ Institute of Biological Chemistry, Academia Sinica, Taipei, Taiwan.

${ }^{2}$ Institute of Microbiology and Immunology, National Yang-Ming University, Taipei, Taiwan.

${ }^{3}$ Institute of Molecular Medicine, College of Medicine, National Taiwan University, Taipei, Taiwan.
} 
to the severe, often fatal, dengue hemorrhagic fever and dengue shock syndrome. The DEN viruses are transmitted to humans by mosquitoes and have become a serious health problem in the tropical and subtropical areas of the world in the last few years. Like other flaviviruses, DEN virus contains an approximately $10.5-\mathrm{kb}$ single positive-strandedRNA genome, which is initially translated into a single polyprotein on infection. The core protein, located at the $\mathrm{N}$ terminus of the polyprotein, forms a structural component of the viral capsid. There is little sequence conservation among the various flavivirus core proteins, but they are similar in size and net positive charge and share an internal hydrophobic segment (Chambers et al., 1990). The core protein of DEN 2 can be detected in the nucleus, but its function is not clear (Bulich and Aaskov, 1992). Many studies on the other member of Flaviviridae family, such as the hepatitis $\mathrm{C}$ virus (HCV), showed that the core protein may have multiple roles in the viral life cycle and can trans-regulates several viral and cellular genes (Shih et al., 1993; Ray et al., 1995, 1997, 1998). In this study, we aimed to explore the possibility of an interaction between the DEN virus core protein and hnRNP K. Several experiments were performed to characterize their physical and functional interactions.

\section{MATERIALS AND METHODS}

\section{Plasmids and constructs}

The C/EBP $\beta$-CAT construct and full-length hnRNP K cDNA were cloned as described (Chang et al., 1995; Miau et al., 1998). The EcoRI fragment of hnRNP K was subcloned into pEGFP$\mathrm{C}$ (Clontech) for eukaryotic GFP-hnRNP K protein expression and was also subcloned into pGEX (Amersham Pharmacia) for glutathione-S transferase (GST) fusion protein production. To construct the truncated mutants, the EcoRI-NdeI fragment (amino acids 1-379), EcoRI-HindIII fragment (amino acids 1-180), XbaI-EcoRI fragment (amino acids 277-464), HindIIIEcoRI fragment (amino acids 179-464), and HindIII-XbaI fragment (amino acids 179-276) were subcloned into pEGFP-C (Clontech) and pGEX (Amersham Pharmacia) vectors. The pEC1-100, pEC1-72, pEC15-100, pEC37-100, and pEC59-100 were constructed by insertion of a series of PCR products that encode DEN virus core protein from amino acids 1 to 100,1 to 72,15 to 100,37 to 100 , and 59 to 100 , respectively, into the pET 29 vector (Invitrogen). The DNA fragment encoding amino acids 1 to 100 and 1 to 72 of the DEN virus core protein were cloned into the pCMV-DS eukaryotic expression vector with the CMV promoter and a tag composed of 8 amino acids of delta antigen (MSRSESKRNR). The cDNA of HuR was isolated by RT-PCR using two primers: 5'-ATGTCTAATGGTTATGAAGAC-3' and 5'-ATGAGCGAGTTATTTGTGGG-3' and RNA from HeLa cells. The cDNA of hnRNP E2 was synthesized by RT-PCR using the primers 5'-CTAGCTGCTCCCCATGCCAC-3' and 5'-ATGGACACCGGTGTGATTG-A3'. The product was cloned into pGEX (Amersham Pharmacia) and pCMV-Tag2 (Stratagene).

\section{In vitro translation}

A series of deletion mutants of DEN virus core protein, including full-length and amino acids 15 to 100,37 to 100,59 to
100 , and 1 to 72 were translated by the TNT-coupled reticulocyte lysate system (Promega). The translated proteins were ${ }^{35} \mathrm{~S}$ Met labeled.

\section{Recombinant protein expression and purification}

All GST fusion proteins were expressed in E. coli strain DH5 $\alpha$, and crude lysates were prepared according to the Amersham Pharmacia manual.

\section{GST binding assay}

Glutathione-Sepharose 4A beads (Amersham Pharmacia) were mixed with $2 \mu \mathrm{g}$ of full-length or deletion-mutant GST-hnRNP K fusion proteins or GST only in $500 \mu \mathrm{l}$ of PBS containing $1 \%$ Triton X-100 on a rotary shaker for $20 \mathrm{~min}$ at room temperature. The beads were washed three times with PBS and then combined with $5 \mu$ l of in vitro-translated ${ }^{35} \mathrm{~S}-\mathrm{la}-$ beled protein in $200 \mu \mathrm{l}$ of binding buffer containing $20 \mathrm{mM}$ HEPES, pH 7.9; $100 \mathrm{mM} \mathrm{NaCl}, 2.5 \mathrm{mM} \mathrm{MgCl}_{2}, 0.1 \mathrm{mM}$ EDTA, $0.05 \%$ NP-40, and $1.5 \%$ Triton X-100 in the presence or absence of RNase A $10 \mu \mathrm{g} / \mathrm{ml}$ on a rotary shaker at room temperature for $30 \mathrm{~min}$. The beads were washed three times with $500 \mu \mathrm{l}$ of binding buffer containing $500 \mathrm{mM} \mathrm{NaCl}$. Finally, the bound proteins were separated by SDS-PAGE followed by autoradiography. In various experiments, nucleic acids were added. Poly $(C), \operatorname{poly}(A)$, poly $(G)$, and poly(U) were purchased from Sigma. The sequence of the sense CT3 oligonucleotide is 5' -AATTCTCCTCCCCACCTTCCCCACCCTCCCCA-3'; the antisense CT3 is the complementary oligonucleotide. The 3' UTR of 15-lipooxygenase, termed LOX-R and LOX-NR, were cloned by PCR and in vitro transcribed to RNA (Ostareck et al., 1997).

\section{Assessment of hnRNP K-mRNA interactions}

The interaction of hnRNP $\mathrm{K}$ and mRNA was assessed as described (Ostrowski et al., 2000). Briefly, GSH beads bearing GST-hnRNP K were mixed with DEN virus core-protein deletion constructs from amino acids 1 to 100 or 1 to 72 . After being washed, $25 \mu \mathrm{g}$ of total RNA from 293T cells was added in the binding buffer containing $10 \mathrm{mM}$ HEPES, pH 7.6; $3 \mathrm{mM}$ $\mathrm{MgCl}_{2}, 2 \mathrm{mM}$ DTT, $40 \mathrm{mM} \mathrm{KCl}, 5 \%$ glycerol, and $0.5 \% \mathrm{NP}-$ 40. The beads were centrifuged, and the supernatant liquid, containing unbound RNA, was saved. After extensive washing with binding buffer, the bound RNAs were eluted with $100 \mu \mathrm{l}$ of elution buffer (10 mM Tris, $\mathrm{pH} 7.5 ; 100 \mathrm{mM} \mathrm{NaCl}, 0.5 \mathrm{mM}$ EDTA, 1\% SDS). RNA was phenol purified and ethanol precipitated, and RNA pellets were dissolved and translated in vitro using rabbit reticulocyte lysate (Promega) in the presence of ${ }^{35} \mathrm{~S}$-Met. The ${ }^{35} \mathrm{~S}$-labeled translational products were separated by SDS-PAGE and analyzed by autoradiography.

\section{Immunoprecipitation and Western blot analysis}

To prepare whole-cell extract (WCE), $1 \times 10^{7} 293 \mathrm{~T}$ cells were resuspended in lysis buffer $(20 \mathrm{mM}$ Tris $\mathrm{HCl}, \mathrm{pH}$ 7.6; 0.4 $\mathrm{M} \mathrm{NaCl}, 1 \mathrm{mM}$ EDTA, $1 \%$ Triton X-100, $1 \mathrm{mM}$ DTT, leupeptin $1 \mu \mathrm{g} / \mathrm{ml}$, pepstatin A $1 \mu \mathrm{g} / \mathrm{ml}$, and PMSF $100 \mu \mathrm{g} / \mathrm{ml}$ ). The cell suspension was rotated at $4^{\circ} \mathrm{C}$ for $30 \mathrm{~min}$ and cleared by centrifugation at $10,000 \times g$ for $10 \mathrm{~min}$. The protein concentration was estimated by the Bio-Rad protein assay. Whole- 
cell extracts ( $1 \mathrm{mg}$ ) were incubated with anti-GFP antibody and protein A Sepharose (Amersham Pharmacia) or anti-Flag M2 beads at $4{ }^{\circ} \mathrm{C}$ for $16 \mathrm{~h}$ in $0.4 \mathrm{ml}$ of lysis buffer containing 0.1 $\mathrm{M} \mathrm{NaCl}$. After extensive washes with lysis buffer, the protein complexes were subjected to $15 \%$ SDS-PAGE. The proteins separated by SDS-PAGE were transferred to Hybond-C membranes (Amersham Pharmacia) and subjected to Western detection by monoclonal antibody 6A1 against delta antigen (kindly provided by Dr. W.-J. Syu).

\section{Cell culture, transfection, and CAT assay}

The 293T and BHK cells were maintained in DMEM (Life Technologies) supplemented with $10 \%$ FBS (Hyclone) and 1\% penicillin-streptomycin (Life Technologies). Transfection was performed using the calcium phosphate precipitation method and followed by CAT assay, as described previously (Chang et al., 1998).

\section{Immunofluorescence staining}

The 293T cells grown on 24-well plates were cotransfected with pEGFP-hnRNP $\mathrm{K}$ and pCMV-DS-core plasmids by the calcium phosphate method. Forty hours after transfection, cells were washed with PBS, fixed with methanol for $20 \mathrm{~min}$ at room temperature, and permeabilized with $0.5 \%$ Triton X-100 in PBS for $10 \mathrm{~min}$. The cells were stained with anti-delta primary antibody and rhodamine-conjugated goat anti-mouse secondary antibody. The stained cells were observed under a fluorescence microscope (Axiovert S100; Zeiss).

\section{RESULTS}

\section{Physical interaction between hnRNP $K$ and DEN virus core protein}

Hepatitis $\mathrm{C}$ virus core protein was previously shown to interact with hnRNP $\mathrm{K}$ and consequently act to relieve the suppressive effect of hnRNP K on the thymidine kinase gene promoter activity (Hsieh et al., 1998). We carried out experiments to explore the possible interaction of the core protein of the other member of the Flaviviridae, the dengue virus, with hnRNP K. The results of the binding assay showed that in vitrotranslated ${ }^{35} \mathrm{~S}$-labeled DEN virus core protein specifically interacted with GST-hnRNP K fusion protein (Fig. 1A). The GST protein alone or another GST fusion construct encoding an RNA-binding protein HuR could not interact with the DEN virus core protein.

It is known that both hnRNP K and DEN virus core protein are RNA-binding proteins. Thus, to exclude the possibility that the DEN virus core protein might be brought down indirectly through its interaction with RNAs, GST pull-down assays were performed after treatment with RNase A. Figure 1B shows that this treatment did not affect the interaction of hnRNP $\mathrm{K}$ with DEN virus core protein, whereas the binding of the HIV gag protein to GST-hnRNP K was decreased. This result suggests that the hnRNP K-DEN virus core protein interaction was not through RNA. The GST-hnRNP K complex could not bring down the ${ }^{35} \mathrm{~S}$-labeled HuR, demonstrating the specificity of the interaction between the DEN virus core protein and hnRNP K.
$\mathbf{A}$

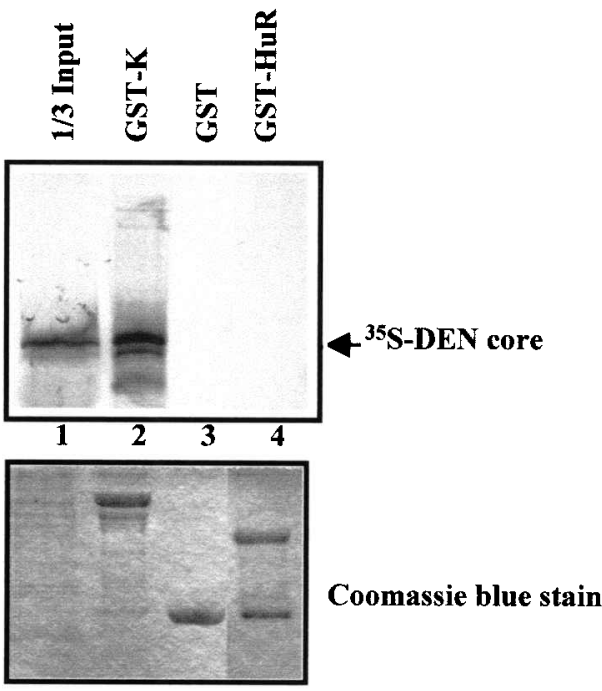

B

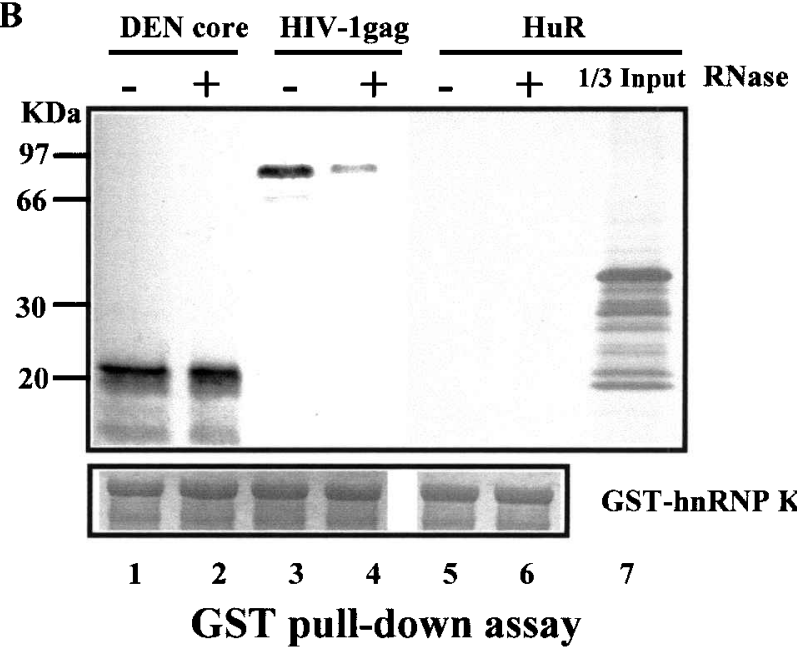

FIG. 1. Protein-protein interaction between DEN virus core protein and hnRNP $\mathrm{K}$ in in vitro GST binding assay. (A) The GST-hnRNP K (lanes 2), GST (lanes 3), or GST-HuR (lanes 4) fusion protein was bound to glutathione-Sepharose $4 \mathrm{~B}$ beads and incubated with in vitro-translated ${ }^{35} \mathrm{~S}$-Met-labeled DEN virus core protein. After extensive washing, bound proteins were analyzed by SDS-PAGE followed by autoradiography Lanes 1 represent $1 / 3$ input of DEN virus core proteins. The gel was stained (Coomassie blue) and autoradiographed. (B) The interaction between DEN virus core protein and hnRNP K could not be blocked by treatment with RNase. Beads bound to GST-hnRNP K were incubated with ${ }^{35} \mathrm{~S}$-labeled proteins in the absence $(-)$ or presence $(+)$ of RNase. Lanes 1 and 2 are DEN virus core protein; lanes 3 and 4 are HIV-1 gag protein; lanes 5 and 6 are HuR protein. Lane 7 is $1 / 3$ input of ${ }^{35} \mathrm{~S}$-Metlabeled HuR.

\section{Characterization of interacting domains responsible} for association between hnRNP $K$ and DEN virus core protein

To dissect the region of hnRNP $\mathrm{K}$ critical for specific binding to the DEN virus core protein, several truncated mutants were 
constructed and expressed in bacteria and eukaryotic cells. The GST pull-down assays showed that the binding activity of GST$\mathrm{K}(1-379)$ was slightly lower than that of GST-K (1-464). The other deletion constructs, including GST-K (1-180), GST-K (179276), GST-K (179-464), and GST-K (277-464), bound poorly with the DEN virus core protein (Fig. 2A). From these results, we could not determine the exact core protein-binding domains on hnRNP K. It appears that an intact molecule of hnRNP K is essential for full DEN virus core protein-binding activity.

Furthermore, to determine whether hnRNP K is capable of binding to DEN virus core protein in cells, coimmunoprecipitation was performed on lysates of cells transiently overexpressing both proteins. The $293 \mathrm{~T}$ cells were transfected with a series of deletion constructs of GFP-hnRNP K and the delta$\mathrm{DEN}$ virus core protein. The whole-cell extracts were isolated and brought down by anti-GFP antibody and protein ASepharose. The immunoprecipitated protein complexes were analyzed by Western blot with anti-delta antigen antibody. The results showed that $\mathrm{K}$ (1-464) and K (179-464), but not K (277464 ) or K (1-180), could bring down the DEN virus core protein (Fig. 2B). The truncated K (179-464) could not bring down the DEN virus core protein in the in vitro-binding assay, but the two could be coimmunoprecipitated from the 293T cell extracts. It is possible that the interaction is mediated indirectly by interacting with other proteins in the cell extracts. We also demonstrated that another hnRNP component, hnRNP E2, could bring down the DEN virus core protein in the immunoprecipitation experiment (Fig. 2C; lanes 1-3). Furthermore, the interaction between them was confirmed by the GST binding assay (Fig. 2C; lanes 4-6). The protein-protein interaction between hnRNP K and E2 has previously been demonstrated (Kim et al., 2000).

The core protein used in this study belongs to the DEN virus of serotype 2, isolated in Taiwan. The amino acid sequence is shown in Figure 3A. The $\mathrm{N}$ and $\mathrm{C}$ termini of the core protein are rich in basic amino acids and belong to hydrophilic regions, whereas the central region (40-60) is the hydrophobic domain. To determine the region on the DEN virus core protein that is responsible for binding to hnRNP $\mathrm{K}$, several truncated constructs, ranging from amino acids 15-100, 37-100, 59-100, and 1-72, were translated in vitro and incubated with GST-hnRNP $\mathrm{K}$ in a binding assay (Fig. 3B). The three N-terminus deletion constructs (aa 15-100, 37-100, and 59-100) retained most of hnRNP K-binding activity, but the C-terminus deletion con-
A
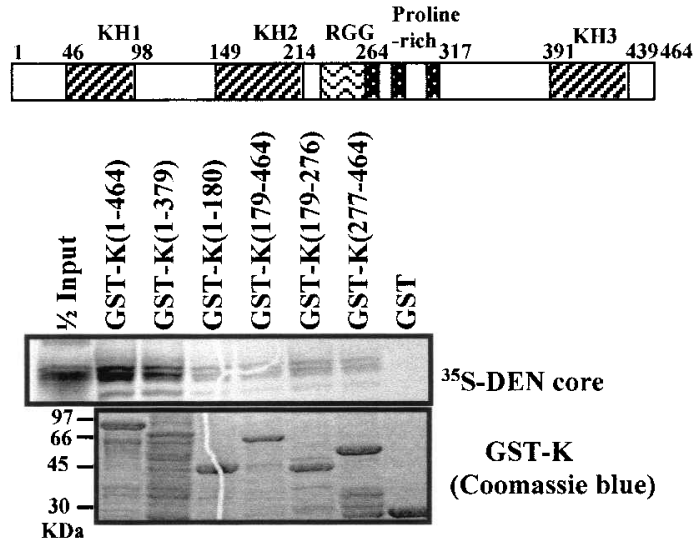

C

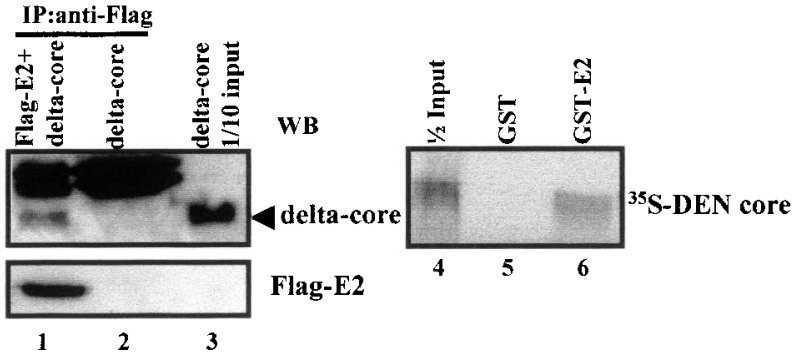

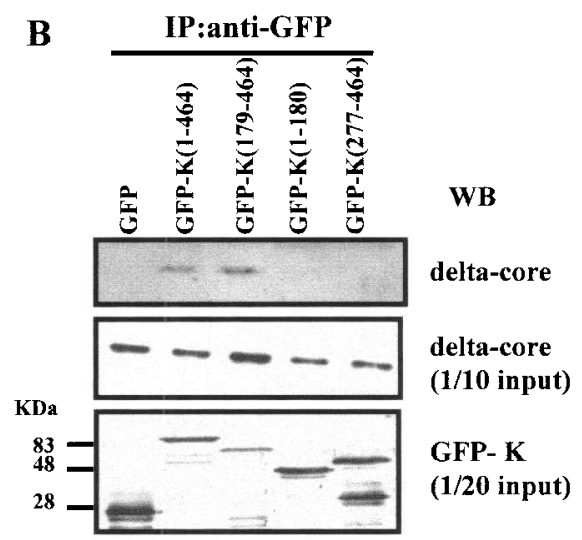

FIG. 2. Mapping of the interaction domains of hnRNP K with DEN virus core protein. (A) Various hnRNP K truncated mutants were fused to GST, including K (1-464), K (1-379), K (1-180), K (179-464), K (179-276), and K (277-464); and GST pulldown assays were performed by mixing with ${ }^{35} \mathrm{~S}$-labeled DEN core protein. The gels were Coomassie blue stained and autoradiographed.(B) The 293T cells were transfected with GFP-hnRNP K constructs K (1-464), K (179-464), K (1-180), or K (277-464) and delta-core proteins. After immunoprecipitation by anti-GFP antibody, the protein complexes were analyzed by Western blotting with anti-delta antibody. The lower gels show the expressed amounts of delta-core and GFP-hnRNP K; $100 \mu \mathrm{g}$ or $50 \mu \mathrm{g}$ of whole-cell extracts were detected by Western blotting with anti-delta or anti-GFP antibody. (C) The 293T cells were transfected with Flag-hnRNP E2 and delta-core protein. Whole-cell extracts were prepared and immunoprecipitated with anti-Flag M2 beads followed by Western blotting using anti-delta antibody (lanes 1-3). Lanes 4-6 represent the GST binding assay. The ${ }^{35}$ S-DEN virus core protein was incubated with beads bound to GST (lane 5) or GST-hnRNP E2 (lane 6). Beads were washed, and bound proteins were subjected to SDS-PAGE. 
A

$\begin{array}{lr}\text { MNQQRKKARNTPFNMLKRER } & 20 \\ \text { NRVSTVQQLTKRFSLGMLQG } & 40 \\ \text { RGPFKLFMALVAFLRFLTIP } & 60 \\ \text { PTAGILKRWGTIKKSKAINV } & 80 \\ \text { FRGFRKEIGRMLNILNRRRR } & 100\end{array}$

B

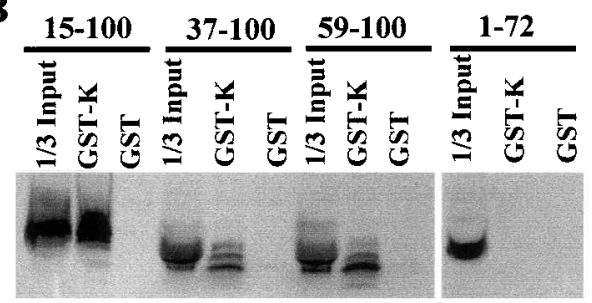

FIG. 3. Characterization of hnRNP K-interacting domains of DEN virus core protein. (A) The amino acid sequence of DEN virus core protein from Taiwan PL046. (B) A series of deletion constructs of DEN core protein, C (15-100), C (37-100), C (59-100), and $\mathrm{C}(1-72)$, were in vitro translated and ${ }^{35} \mathrm{~S}$ labeled, then incubated with beads bound to GST-hnRNP K or GST for binding assay.

struct (aa 1-72) had lost the activity completely. This result indicates that the hydrophilic amino acid region from residues 73 to 100 of the DEN virus core protein may be involved in the interaction with hnRNP K.

\section{Subcellular localization of hnRNP $K$ and the DEN virus core protein}

To further demonstrate the interaction between hnRNP K and the DEN virus core protein in vivo, immunofluorescence staining of both proteins in cells was performed. Both 293T and BHK cells were cotransfected with plasmids encoding GFP-hnRNP K and delta core. The location of hnRNP K was observed by green fluorescence, and the location of the DEN virus core protein was detected with an antibody against the delta tag. The hnRNP K protein was found exclusively in the nuclei of both $293 \mathrm{~T}$ and BHK cells (Fig. 4B, E). The DEN virus core protein seemed to have a broader distribution, including both the nucleus and the cytoplasm in both cells (Fig. 4C, F). Double exposure indicated that the two proteins were present within the nuclei (data not shown). To exclude the possible effect of the tag on the cellular localization of the fusion protein, the Flagtagged core protein also was used in immunofluorescencestaining. The location of Flag-tagged core protein was identical to that of the delta-tagged protein (data not shown).

\section{Effects of nucleic acid binding on interaction of DEN virus core protein with hnRNP K}

The hnRNP K protein has both RNA-binding and DNA-binding properties. Because the functions of hnRNP K might be regulated by binding to RNA and DNA, we next tested the effect of the cognate nucleic acid motifs on the interaction between the DEN virus core protein and hnRNP K. We added nucleic acids to the GST-binding assays. The GST-K beads were preincubated with nucleic acids for $30 \mathrm{~min}$ before the DEN virus core protein was added (Fig. 5A). The specific hnRNP K-binding nucleic acid elements, such as poly(C), LOX-R, and sense CT3 oligonucleotide, could diminish the hnRNP K-DEN core protein complex dramatically. Poly(U) moderately decreased the interaction between hnRNP K and the DEN virus core protein, whereas other nucleic acid elements such as poly(A), poly $(\mathrm{G})$, antisense CT3, and LOX-NR, did not alter the binding. The inhibitory effect of specific nucleic acid elements on the protein interaction was decreased when hnRNP K and the core protein were incubated before the addition of the nucleic acids (data not shown). These findings suggest that the presence of specific hnRNP K-binding nucleic acids could block the interaction between the core protein and hnRNP K.

We further examined whether the association with the core protein could mediate the nucleic acid-binding activity of hnRNP K. We tested the general mRNA-binding activity of hnRNP K in the presence of the DEN virus core protein. The DEN virus core protein deletion construct (aa 1-72), whose inability to interact with hnRNP K has been demonstrated above, served as a negative control in this experiment. Beads bearing GSThnRNP K were incubated with DEN virus core protein construct 1-72 (Fig. 5B; lanes 1 and 3) or 1-100 (Fig. 5B; lanes 2 and 4). After washes, $25 \mu \mathrm{g}$ of total RNA prepared from $293 \mathrm{~T}$ cells was mixed with these beads. The beads were spun down, and the unbound fraction was collected. Bound RNAs were

\section{A}

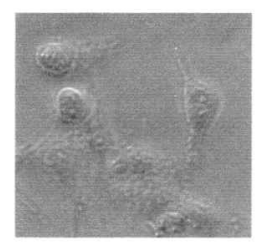

$\mathbf{B}$
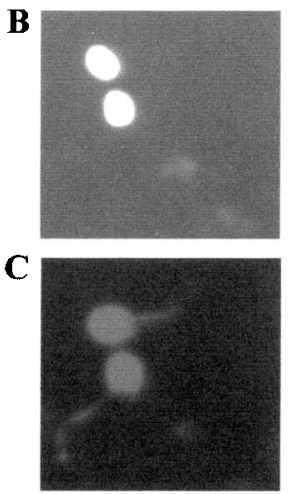

293T

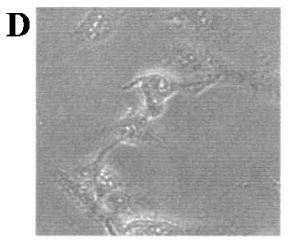

phase contrast
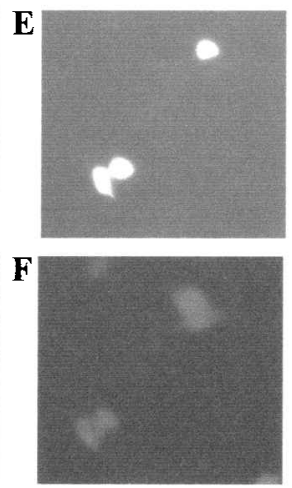

BHK

\section{GFP-K}

delta-core
FIG. 4. Subcellular localization of hnRNP K and DEN virus core protein. The $293 \mathrm{~T}(\mathbf{A}, \mathbf{B}, \mathbf{C})$ and BHK $(\mathbf{D}, \mathbf{E}, \mathbf{F})$ cells were cotransfected with plasmids expressing GFP-hnRNP K and delta-DEN virus core protein $1-100$. Cells were fixed $40 \mathrm{~h}$ posttransfection. Immunofluorescence staining was performed using anti-delta primary antibody and the rhodamine-conjugated anti-mouse IgG secondary antibody. (A, D) Phase-contrast images of the cells. (B, E) Fluorescence indicates GFP-hnRNP K. $(\mathbf{C}, \mathbf{F})$ Rhodamine indicates delta-DEN virus core protein. 

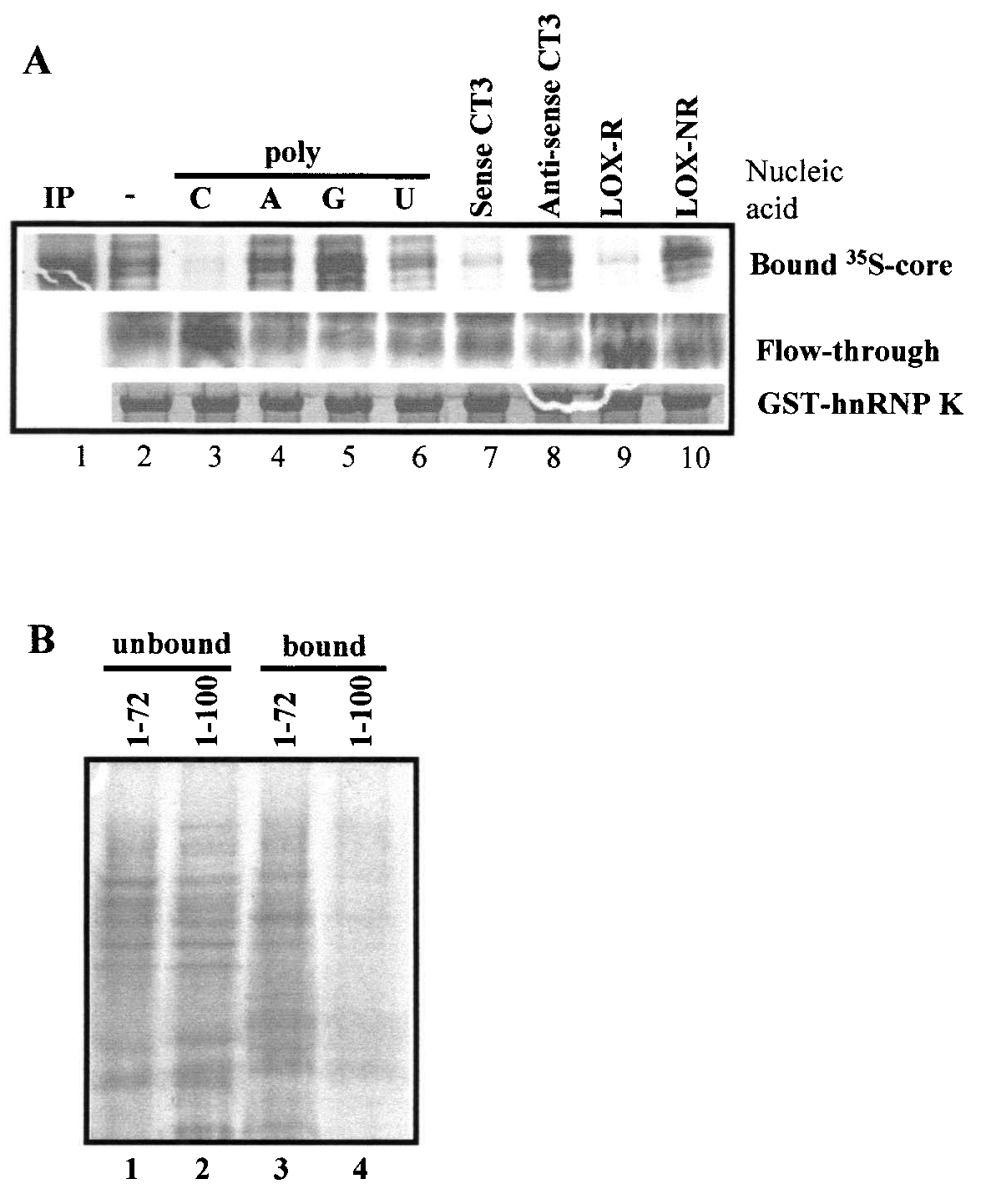

FIG. 5. Interaction of hnRNP K and DEN virus core protein in the presence of nucleic acids. (A) In vitro binding assay was performed by incubation of glutathione beads bound to GST-K (1-464) with $10 \mu \mathrm{g} / \mathrm{ml}$ of poly(C), poly(A), poly(G), poly(U), single-stranded sense CT3 oligonucleotide, anti-sense CT3 oligonucleotide, $50 \mathrm{ng}$ of LOX-R RNA, or $50 \mathrm{ng}$ of LOX-NR RNA for $30 \mathrm{~min}$. Then ${ }^{35} \mathrm{~S}$-labeled DEN virus core protein was added. The gel was Coomassie blue stained and autoradio-graphed The flowthrough from each binding assay is presented. Lane 1 represents $1 / 2$ input of ${ }^{35} \mathrm{~S}$-DEN virus core protein. (B) Beads bound to GST-hnRNP K were mixed with in vitro-translated DEN virus core protein 1-100 (lanes 2 and 4) or 1-72 (lanes 1 and 3). After washing, $25 \mu \mathrm{g}$ of total RNA from $293 \mathrm{~T}$ cells was added. The unbound and bound RNAs were further translated in vitro and analyzed by SDS-PAGE and autoradiography.

eluted with RNA elution buffer. The bound and unbound RNAs were in vitro translated, and the ${ }^{35} \mathrm{~S}$-labeled products were analyzed by SDS-PAGE. The result showed that hnRNP K, when in the presence of DEN virus core protein 1-100, bound a smaller fraction of the mRNAs than in the presence of DEN virus core protein 1-72 (Fig. 5B). This result indicated that an association with the DEN virus core protein could decrease hnRNP K's nucleic acid-binding ability.

\section{Role of DEN virus core protein-hnRNP $K$ interaction in hnRNP K-mediated gene expression regulation}

In our previous report, hnRNP $\mathrm{K}$ was shown to serve as a negative regulator to repress $\mathrm{C} / \mathrm{EBP} \beta$-mediated gene activation (Miau et al., 1998). To analyze the functional interaction between DEN virus core protein and hnRNP K, we tested whether the coexpression of hnRNP $\mathrm{K}$ and the DEN virus core protein could affect $\mathrm{C} / \mathrm{EBP} \beta$ trans-activation activity. Both $\mathrm{BHK}$ and 293 T cells were transfected with plasmids containing a CAT reporter gene driven by the $c / e b p \beta$ promoter, along with expression vectors of $\mathrm{C} / \mathrm{EBP} \beta$, hnRNP K, and the DEN virus core pro- tein (Fig. 6). Consistent with our previous result, C/EBP $\beta$ transactivated the $c / e b p \beta$ promoter, and cotransfection of hnRNP K with $\mathrm{C} / \mathrm{EBP} \beta$ resulted in a dramatic inhibition of the $\mathrm{C} / \mathrm{EBP} \beta$ induced activity (Fig. 6; columns 5 and 6). Coexpression of the DEN virus core protein 1-100 construct could restore the $\mathrm{C} / \mathrm{EBP} \beta$ activity that was repressed by hnRNP K (Fig. 6; columns 7 and 8). The truncated DEN virus core protein 1-72 construct, which lacked the hnRNP K-binding activity, could not relieve the repressive effect of hnRNP K on the C/EBP $\beta$ mediated promoter trans-activation (Fig. 6, columns 9 and 10). The autoradiograph result in the lower panel shows the expression of the DEN virus core protein 1-100 and 1-72 constructs. Taken together, the biochemical interaction between hnRNP K and the DEN virus core protein may have a functional consequence of modulating hnRNP K-mediated transcription activity.

\section{DISCUSSION}

In this paper, we have described the interaction between hnRNP K and the DEN virus core protein. Our analyses in- 

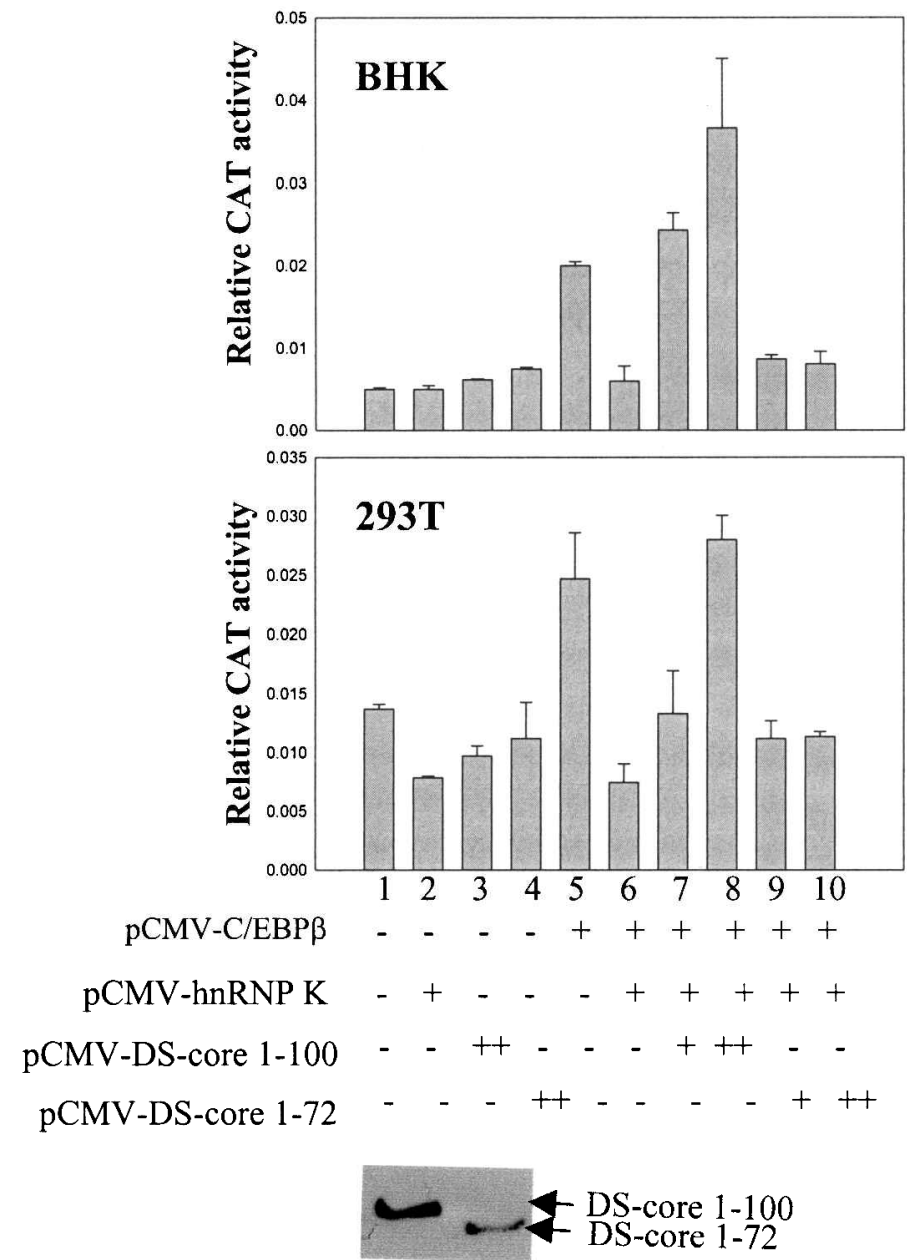

FIG. 6. The functional interaction of DEN virus core protein and hnRNP K. The BHK and 293T cells were cotransfected with $0.25 \mu \mathrm{g}$ of $c / e b p \beta$-CAT reporter plasmid, $0.5 \mu \mathrm{g}$ of pSV- $\beta$-galactosidase, and expression plasmids such as $0.1 \mu \mathrm{g}$ of pCMV-C/EBP $\beta$, $0.5 \mu \mathrm{g}$ of pCMV-hnRNP K, and $0.5 \mu \mathrm{g}(+)$ or $1 \mu \mathrm{g}(++)$ of pCMV-DS-core as indicated. The relative CAT activity has been normalized with $\beta$-galactosidase activity. At bottom, expression of delta-core 1-100 and delta-core 1-72 in the 293T cells.

dicated that the interactions occur in vitro and in vivo and are not RNA dependent. However, with these experiment approaches, we currently cannot rule out the possibility that the interactions are mediated indirectly through the involvement of other proteins in the reticulocyte lysates and cell extracts. The hnRNP K protein is versatile, involved in many cellular processes. Several reports have implicated hnRNP $\mathrm{K}$ in the regulation of cell growth. Moreover, hnRNP K has been shown to be activated by growth factors and consequently enhances the expression of c-myc, which plays an important role in cell cycle progression (Mandal et al., 2001). Upregulation of hnRNP $\mathrm{K}$ has been observed in SV40-transformed cells (Dejgaard et al., 1994). It has also been reported that high levels of either human or Drosophila hnRNP K in the imaginal discs can induce programmed cell death (Charroux et al., 1999). The finding of the interaction between the DEN virus core protein and hnRNP K in our study suggests potential roles for the core protein in regulating cellular gene expression and cell proliferation. Indeed, the DEN virus has been shown to induce apoptosis in mouse neuroblastoma and human hepatoma cells (Despres et al., 1996; Marianneau et al., 1997).

As described earlier, hnRNP K contains multiple nucleic acidand protein-interactive domains. It may simultaneously interact with its partners to form multiple protein or protein-nucleic acid complexes. The binding partners may also serve as regulators of the formation of hnRNP K-associated complexes. For example, the interaction of hnRNP K with zik1 or with Y-box binding factor is abolished by specific nucleic acid elements (Denisenko et al., 1996; Shnyreva et al., 2000). However, hnRNP K can simultaneously bind both K protein kinase and cSrc or Vav (Van Seuningen et al., 1995). Thus, the interaction between hnRNP K and the DEN virus core protein might be regulated by another interacting partner (nucleic acids or proteins). As shown in Figure 5A, a specific hnRNP K-binding nucleic acid element could block the hnRNP K-DEN core protein interaction. On the other hand, the mRNA binding assay (Fig. 5B) showed that the mRNA binding activity of hnRNP K-DEN virus core protein complex is different from that of hnRNP $\mathrm{K}$ alone.

The DEN2 and DEN4 core proteins have been detected in the 
nucleus (Bulich and Aaskov, 1992; Tadano et al., 1989). Three putative nuclear localization domains, 6KKAR9, 73KKSK76, and 85RKeigrmlnilnRRRR100, have been identified in the core protein (Bulich and Aaskov, 1992). By indirect immunofluorescence staining, we observed that both hnRNP K and the DEN virus core protein are present in the nuclei (Fig. 4). Therefore, cellular processes that are nuclear events (such as transcription) were explored to functionally characterize this interaction. The engagement of different factors by hnRNP K may result in both activation and repression of gene transcription (Michelotti et al., 1996; Miau et al., 1998). The functional significance of the DEN virus core protein-hnRNP K complex in transcription regulation was demonstrated by the $c / e b p \beta$ promoter activity. Our results demonstrated that the suppressive effect of hnRNP $\mathrm{K}$ on the $\mathrm{C} / \mathrm{EBP} \beta$ trans-activation could be overcome by the presence of the DEN virus core protein. One of the possible mechanisms of the DEN virus core protein's effect may be blockage of the association between hnRNP K and C/EBP $\beta$.

To further characterize the biochemical relation among hn$\mathrm{RNP} \mathrm{K}, \mathrm{C} / \mathrm{EBP} \beta$, and the DEN virus core protein, we performed immunoprecipitation with whole-cell extracts of $293 \mathrm{~T}$ cells cotransfected with pCMV-hnRNP K, pCMV-C/EBP $\beta$, along with pCMV-DS-core1-100 or pCMV-DS-core1-72. The results showed that anti-hnRNP $\mathrm{K}$ polyclonal antibodies could bring down equivalent amounts of $\mathrm{C} / \mathrm{EBP} \beta$ from the whole-cell extracts containing either core 1-100 or core 1-72 (data not shown). One possible explanation is that because of the high level of endogenous hnRNP K, immunocomplexes obtained in the setting of ectopic protein overexpression might not reflect the actual in vivo protein complex distribution. Another possibility is that the DEN virus core protein does not affect the interaction of hnRNP $\mathrm{K}$ with $\mathrm{C} / \mathrm{EBP} \beta$ but alters the interacting components of the hn$\mathrm{RNP} \mathrm{K}-\mathrm{C} / \mathrm{EBP} \beta$ complex. If we further clarify this effect on the complex composition, we will have a better understanding of how hnRNP K represses gene expression.

In the past, most studies concerning the DEN virus focused on the immunologic aspect. In this report, we established novel molecular properties of the DEN virus core protein, which are the interaction with cellular hnRNP $\mathrm{K}$ and a potential regulatory role in $\mathrm{C} / \mathrm{EBP} \beta$ activity. Because $\mathrm{C} / \mathrm{EBP} \beta$ is an important transcription factor during the acute-phase response and virus infection (Akira and Kishimoto, 1992), our investigation may help to explain the pathogenesis of the DEN virus infection. Recently, in DEN virus-infected liver cells, $\mathrm{C} / \mathrm{EBP} \beta$ has been reported to be activated and found to induce the expression of the chemokine RANTES (Lin et al., 2000). The biologic significance of the interaction of the DEN virus core protein with hnRNP K in DEN virus-infected cells will be a future subject of investigation.

In addition to hnRNP K, we have also demonstrated the interaction between hnRNP E2 and the DEN virus core protein. The hnRNP E2 protein is similar to hnRNP $\mathrm{K}$ in that it also contains the three KH domains (Leffers et al., 1995; OstareckLederer et al., 1998). Therefore, it is most likely that the $\mathrm{KH}$ domains of both proteins are responsible for the interaction with the DEN virus core protein. Cooperative activity of hnRNP E2 and K on cellular or viral RNA translation has been reported by Ostareck et al. (1997) and Collier et al. (1998). The hnRNPE2 protein binds to poliovirus IRES and facilitates viral translation (Blyn et al., 1997; Garmarnik and Andino, 1997).
Moreover, it is reported to bind to the IRES of the hepatitis C virus. Taken together, these findings imply that the DEN virus core protein interacts with cellular hnRNP to affect viral and cellular RNA translation.

\section{ACKNOWLEDGMENTS}

We thank Dr. W.-J. Syu, Institute of Microbiology and Immunology, National Yang-Ming University, Taipei, Taiwan, for kindly providing monoclonal antibody 6A1 against delta antigen. We thank Rui Chao for technical assistance and Bertrand Chin-Ming Tan for critical reading of the manuscript. This work was supported by National Science Council Grant NSC892311-B-001-070.

\section{REFERENCES}

AKIRA, S., and KISHIMOTO, T. (1992). IL-6 and NF-IL6 in acutephase response and viral infection. Immunol. Rev. 127, 25-50.

BLYN, L.B., TOWNER, J.S., SEMLER, B.L., and EHRENFELD, E. (1997). Requirement of poly (rC) binding protein 2 for translation of poliovirus RNA. J. Virol. 71, 6243-6246.

BOMSZTYK, K., VAN SEUNINGEN, I., SUZUKI, H., DENISENKO, O., and OSTROWSKI, J. (1997). Diverse molecular interactions of the hnRNP K protein. FEBS Lett. 403, 113-115.

BULICH, R., and AASKOV, J.G. (1992). Nuclear localization of dengue 2 virus core protein detected with monoclonal antibodies. J. Gen. Virol. 73, 2999-3003.

BUSTELO, X.R., SUEN, K.L., MICHAEL, W.M., DREYFUSS, G., and BARBACID, M. (1995). Association of the vav proto-oncogene product with poly(rC)-specific RNA-binding proteins. Mol. Cell. Biol. 15, 1324-1332.

CHAMBERS, T.J., HAHN, C.S., GALLER, R., and RICE, C.M. (1990). Flavivirus genome organization, expression, and replication. Annu. Rev. Microbiol. 44, 649-688.

CHANG, C.J., CHEN, Y.L., and LEE, S.C. (1998). Coactivator TIF1 $\beta$ interacts with transcription factor $\mathrm{C} / \mathrm{EBP} \beta$ and glucocorticoid receptor to induce $\alpha 1$-acid glycoprotein gene expression. Mol. Cell. Biol. 18, 5880-5887.

CHANG, C.-J., SHEN, B.-J., and LEE, S.-C. (1995). Autoregulated induction of the acute-phase response transcription factor gene, agp/ebp. DNA Cell Biol. 14, 529-537.

CHARROUX, B., ANGELATS, C., FASANO, L., KERRIDGE, S., and VOLA, C. (1999). The levels of the bancal product, a Drosophila homologue of vertebrate hnRNP K protein, affect cell proliferation and apoptosis in imaginal disc cells. Mol. Cell. Biol. 19, 7846-7856.

COLLIER, B., GOOBAR-LARSSON, L., SOKOLOWSKI, M., and SCHWARTZ, S. (1998). Translational inhibition in vitro of human papillomavirus type $16 \mathrm{~L} 2 \mathrm{mRNA}$ mediated through interaction with heterogenous ribonucleoprotein $\mathrm{K}$ and poly $(\mathrm{rC})$-binding protein 1 and 2. J. Biol. Chem. 273, 22648-22656.

DEJGAARD, K., LEFFERS, H., RASMUSSEN, H.H., MADSEN, P., KRUSE, T.A., GESSER, B., NIELSEN, H., and CELIS, J.E. (1994). Identification, molecular cloning, expression and chromosome mapping of a family of transformation upregulated hnRNP-K proteins derived by alternative splicing. J. Mol. Biol. 236, 33-48.

DENISENKO, O.N., O'NEILL, B., OSTROWSKI, J., SEUNINGEN, I.V., and BOMSZTYK, K. (1996). Zik1, a transcriptional repressor that interacts with the heterogeneous nuclear ribonucleoprotein particle K protein. J. Biol. Chem. 271, 27701-27706.

DESPRES, P., FLAMAND, M., CECCALDI, P.-E., and DEUBEL, V. 
(1996). Human isolates of dengue virus type-1 induce apoptosis in mouse neuroblastoma cells. J. Virol. 70, 4090-4096.

DREYFUSS, G., MATUNIS, G.M., PINOL-ROMA, S., and BURD, C.G. (1993). hnRNP proteins and the biogenesis of mRNA. Annu. Rev. Biochem. 62, 289-321.

DU, Q., MELNIKOVA, I.N., and GARDNER, P.D. (1998). Differential effects of heterogeneous nuclear ribonucleoprotein $\mathrm{K}$ on Sp1and Sp3-mediated transcriptional activation of a neuronal nicotinic acetylcholine receptor promoter. J. Biol. Chem. 273, 19877-19883.

GAMARNIK, A.V., and ANDINO, R. (1997). Two functional complexes formed by $\mathrm{KH}$ domain containing proteins with the $5^{\prime}$ noncoding region of poliovirus RNA. RNA 3, 882-892.

HOBERT, O., JALLAL, B., SCHLESSINGER, J., and ULLRICH, A. (1994). Novel signaling pathway suggested by SH3 domain-mediated $\mathrm{p} 59 \mathrm{vav} / \mathrm{heterogeneous}$ ribonucleoprotein $\mathrm{K}$ interaction. J. Biol. Chem. 269, 20225-20228.

HSIEH, T.-Y., MATSUMOTO, M., CHOU, H.-C., SCHNEIDER, R., HWANG, S.B., LEE, A.S., and LAI, M.M.C. (1998). Hepatitis C virus core protein interacts with heterogeneous nuclear ribonucleoprotein K. J. Biol. Chem. 273, 17651-17659.

KIM, J.H., HAHM, B., KIM, Y.K., CHOI, M., and JANG, S.K. (2000). Protein-protein interaction among hnRNPs shuttling between nucleus and cytoplasm. J. Mol. Biol. 298, 395-405.

KRECIC, A.M., and SWANSON, M.S. (1999). hnRNP complexes: Composition, structure, and function. Curr. Opin. Cell Biol. 11,363371.

LEE, M.-H., MORI, S., and RAYCHAUDHURI, P. (1996). Trans-activation by the hnRNP K protein involves an increase in RNA synthesis from the reporter genes. J. Biol. Chem. 271, 3420-3427.

LEFFERS, H., DEJGAARD, K., and CELIS, J.E. (1995). Characterization of two major cellular poly(rC)-binding human proteins, each containing three K-homologous (KH) domains. Eur. J. Biochem. 230, $447-453$.

LIN, Y.L., LIU, C.C., CHUANG, J.I., LEI, H.Y., YEH, T.M., LIN, Y.S., HUANG, Y.H., and LIU, H.S. (2000). Involvement of oxidative stress, NF-IL6, and RANTES expression in dengue-2-virus-infected human liver cells. Virology 276, 114-126.

MANDAL, M., VADLAMUDI, R., NGUYEN, D., WANG, R.-A., COSTA, L., BAGHERI-YARMAND, R., MENDELSOHN, J., and KUMAR, R. (2001). Growth factors regulate heterogeneous nuclear ribonucleoprotein $\mathrm{K}$ expression and function. J. Biol. Chem. 276, 9699-9704.

MARIANNEAU, P., CARDONA, A., EDELMAN, L., DEUBEL, V., and DESPRES, P. (1997). Dengue virus replication in human hepatoma cells activates NF-kappa B which in turn induces apoptotic cell death. J. Virol. 71, 3244-3249.

MIAU, L.H., CHANG, C.J., SHEN, B.-J., TSAI, W.H., and LEE, S.C. (1998). Identification of heterogeneous nuclear ribonucleoprotein $\mathrm{K}$ (hnRNP K) as a repressor of $\mathrm{C} / \mathrm{EBP} \beta$-mediated gene activation. J. Biol. Chem. 273, 10784-10791.

MICHAEL, W.M., EDER, P.S., and DREYFUSS, G. (1997). The K nuclear shuttling domain: A novel signal for nuclear import and nuclear export in the hnRNP K protein. EMBO J. 16, 3587-3598.

MICHELOTTI, E.F., MICHELOTTI, G.A., ARONSOHN, A.I., and LEVENS, D. (1996). Heterogeneous nuclear ribonucleoprotein $\mathrm{K}$ is a transcription factor. Mol. Cell. Biol. 16, 2350-2360.

OSTARECK, D.H., OSTARECK-LEDERER, A., WILM, M., THIELE, B.J., MANN, M., and HENTZE, M.W. (1997). mRNA silencing in erythroid differentiation: hnRNP K and hnRNP E1 regulate 15-lipoxygenase translation from the $3^{\prime}$ end. Cell 89, 597-606. OSTARECK-LEDERER, A., OSTARECK, D.H., and HENTZE, M.W. (1998). Cytoplasmic regulatory functions of the KH-domain proteins hnRNPs K and E1/E2. Trends Biochem. Sci. 23, 409-411.

OSTROWSKI, J., SCHULLERY, D.S., DENISENKO, O.N., HIGAKI,
Y., WATTS, J., AEBERSOLD, R., STEMPKA, L., GSCHWENDT, M., and BOMSZTYK, K. (2000). Role of tyrosine phosphorylation in the regulation of the interaction of heterogeneous nuclear ribonucleoprotein $\mathrm{K}$ protein with its protein and RNA partners. J. Biol. Chem. 275, 3619-3628.

RAY, R.B., LAGGING, L.M., MEYER, K., STEELE, R., and RAY, B. (1995). Transcriptional regulation of cellular and viral promoter by hepatitis C virus core protein. Virus Res. 37, 209-220.

RAY, R.B., MEYER, K., SHRIVASTAVA, A., AGGARWALAND, B.B., and RAY, R. (1998). Inhibition of tumor necrosis factor (TNFalpha)-mediated apoptosis by hepatitis C virus core protein. J. Biol. Chem. 273, 2256-2259.

RAY, R.B., STEELE, R., MEYER, K., and RAY, R. (1997). Transcriptional repression of $\mathrm{p} 53$ promoter by hepatitis $\mathrm{C}$ virus core protein. J. Biol. Chem. 272, 10983-10986.

SCHULLERY, D.S., OSTROWSKI, J., DENISENKO, O.N., STEMPKA, L., SHNYREVA, M., SUZUKI, H., GSCHWENDT, M., and BOMSZTYK, K. (1999). Regulated interaction of protein kinase $\mathrm{C} \delta$ with the heterogeneous nuclear ribonucleoprotein $\mathrm{K}$ protein. $\mathrm{J}$. Biol. Chem. 274, 15101-15109.

SHIH, C.-M., LO, S.J., MIYAMURA, T., CHEN, S.-Y., and LEE, Y.-H.W. (1993). Suppression of hepatitis B virus expression and replication by hepatitis $\mathrm{C}$ virus core protein in $\mathrm{Hu}-7$ cells. J. Virol. 67, 5823-5832.

SHNYREVA, M., SCHULLERY, D.S., SUZUKI, H., HIGAKI, Y., and BOMSZTYK, K. (2000). Interaction of two multifunctional proteinsheterogeneous nuclear ribonucleoprotein $\mathrm{K}$ and $\mathrm{Y}$-box-binding protein. J. Biol. Chem. 275, 15498-15503.

SIOMI, H., MATUNIS, M.J., MICHAEL, W.M., and DREYFUSS, G. (1993). The pre-mRNA binding K protein contains a novel evolutionary conserved motif. Nucleic Acids Res. 21, 1193-1198.

TADANO, M., MAKINO, Y., FUKUNAGA, T., OKUNO, Y., and FUKAI, K. (1989). Detection of dengue 4 virus core protein in the nucleus I: A monoclonal antibody to dengue 4 virus reacts with the antigen in the nucleus and cytoplasm. J. Gen. Virol. 70, 1409-1415.

TAKIMOTO, M., TOMONAGA, T., MATUNIS, M., AVIGAN, M., KRUTZSCH, H., DREYFUSS, G., and LEVENS, D. (1993). Specific binding of heterogeneous ribonucleoprotein particle protein $\mathrm{K}$ to the human c-myc promoter in vitro. J. Biol. Chem. 268, 1824918258.

TOMONAGA, T., and LEVENS, D. (1995). Heterogeneous nuclear ribonucleoprotein $\mathrm{K}$ is a DNA-binding transactivator. J. Biol. Chem. 270, 4875-4881.

VAN SEUNINGEN, I., OSTROWSKI, J., BUSTELO, X.R., and BOMSZTYK, K. (1995). The K protein domain that recruits the interleukin 1-responsive $\mathrm{K}$ protein kinase lies adjacent to a cluster of cSrc and vav SH3-binding sites. J. Biol. Chem. 270, 26976-26985. WEIGHARDT, F., BIAMONTI, G., and RIVA, S. (1996). The roles of heterogeneous nuclear ribonucleoproteins (hnRNP) in RNA metabolism. BioEssays 18, 747-756.

Address reprint requests to: Dr. Ching-Jin Chang Institute of Biological Chemistry Academia Sinica

No. 1 Sec. 4 Roosevelt Road Taipei, Taiwan

E-mail: chingjin@gate.sinica.edu.tw

Received for publication April 18, 2001; received in revised form June 5, 2001; accepted July 11, 2001. 